\title{
Synthesizing knowledge of the Claybelt to promote sustainable forest management
}

\author{
by P. Lefort ${ }^{1}$, B. Harvey ${ }^{2}$, J. Parton ${ }^{3}$ and G.K.M. Smith ${ }^{4}$
}

A review of the scientific literature relevant to the Claybelt region was undertaken under the initiative of Lake Abitibi Model Forest (LAMF) and in collaboration with the Canadian Forest Service, the Ontario and Quebec Ministries of Natural Resources and the NSERC-UQAT-UQAM (Natural Sciences and Engineering Research Council - Université du Québec en Abitibi-Témiscamingue Université du Québec à Montréal) Industrial Chair in Sustainable forest Management. The objective was to synthesize this information in order to develop better forestry practices and identify knowledge and research gaps. Forestry-related knowledge was gathered on six broad topics: i) natural disturbances, ii) forest ecosystems, iii) past and present forest practices, iv) biological diversity, v) forest management and vi) examples of current applications of natural disturbance-based forest management. The work allowed us to synthesize a large body of knowledge into one publication that will be a useful reference for foresters in both provinces.

Keywords: biodiversity, Claybelt, even-aged/uneven-aged forests, fire, silvicultural practices

Sous l'initiative de la Forêt Modèle du Lac Abitibi (FMLA) et en collaboration avec le Service canadien des forêts, les Ministères des Ressources naturelles de l'Ontario et du Québec, et la Chaire industrielle CRSNG-UQAT-UQAM (Conseil de recherches en sciences naturelles et en génie du Canada - Université du Québec en Abitibi-Témiscamingue et Université du Québec à Montréal) en aménagement forestier durable, une revue de la littérature scientifique pertinente à la Ceinture d'argile a été réalisée. L'objectif était de synthétiser cette information afin de favoriser l'amélioration des pratiques forestières et d'identifier des champs de recherche où il manquait des connaissances. Les connaissances forestières ont été compilées sur six volets: i) les perturbations naturelles, ii) les écosystèmes forestiers, iii) les pratiques sylvicoles passées et présentes, iv) la diversité biologique, v) l'aménagement des forêts et vi) des exemples d'application d'aménagement forestier basé sur les perturbations naturelles. Les résultats nous ont permis de résumer les connaissances actuelles en une publication qui devrait fournir une référence utile pour les forestiers des deux provinces.

Mots-clés: biodiversité, Ceinture d'argile, feu, forêt équienne/inéquienne, pratiques sylvicoles

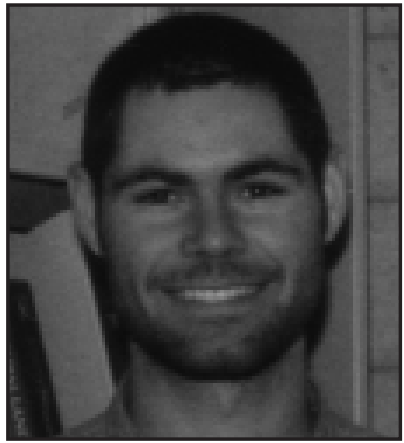

P. Lefort

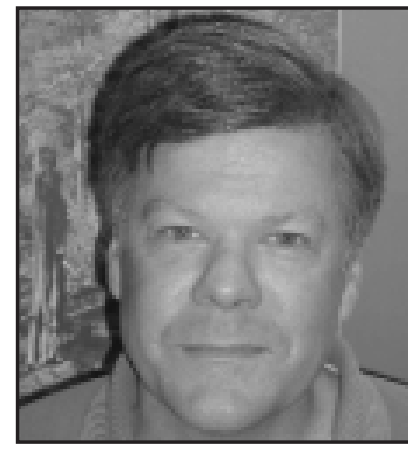

B. Harvey

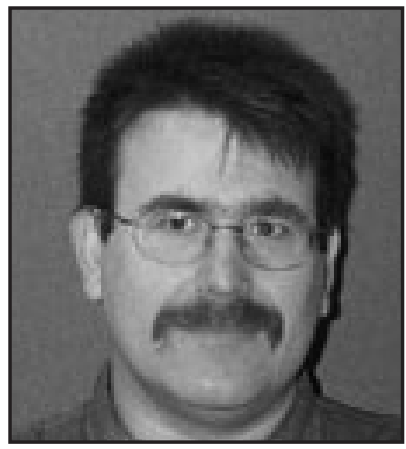

J. Parton

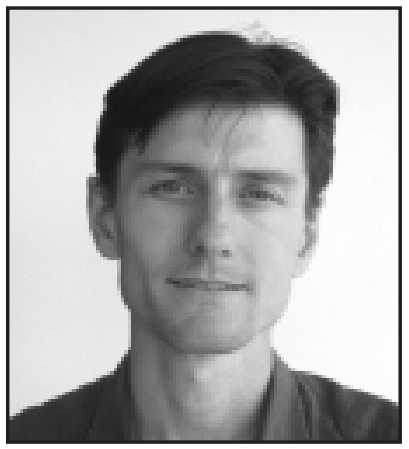

G.K.M. Smith

\section{Introduction}

The Claybelt is a large physiographic region located within northeastern Ontario and northwestern Quebec, in Forest Sec-

\footnotetext{
${ }^{1}$ Groupe de Recherche en Écologie Forestière Inter-universitaire and Département des sciences biologiques, Université du Québec à Montréal, C.P. 8888, Succ. Centre-Ville, Montréal, Québec H3C 3P8. E-mail: c1000@er.uqam.ca ${ }^{2}$ Chaire industrielle CRSNG-UQAT-UQAM en Aménagement forestier durable, Université du Québec en Abitibi-Témiscamingue, 445, boulevard de l'Université, Rouyn-Noranda, Québec J9X 5E4. E-mail: brian.harvey@uqat.ca

${ }^{3}$ Ministry of Natural Resources, Northeast Science \& Information Section, Hwy 101 East., P.O. Bag 3020, South Porcupine, Ontario P0N 1H0. E-mail: john.parton@mnr.gov.on.ca.

${ }^{4}$ Natural Resources Canada, Canadian Forest Service, Great Lakes Forestry Centre, 1219 Queen St. East., Sault Ste.Marie, Ontario P6A 2E5. E-mail gusmith@nrcan.gc.ca. Corresponding author.
}

tion B.4 (Northern Clay)(Rowe 1972). Research activities in the region, most notably the programs of the Lake Abitibi Model Forest (LAMF) in Ontario, and the Lake Duparquet Research and Teaching Forest (LDRTF) in Quebec, have improved our understanding of the Claybelt ecosystem, and of forest operations in the region, and led to increased discussion among forest stakeholders. Given the history of research undertaken in the region, there is an opportunity to develop forest management strategies suited specifically to the Claybelt. This article provides a five-part summary of a LAMF project intended to synthesize knowledge about the Claybelt forest. One objective of the project was to determine the potential of generalizing the innovative 3-cohort forest management model initiated in Quebec by researchers from the NSERC-UQAT-UQAM Industrial Chair in Sustainable Forest Management (SFM Industrial Chair) and the Canadian Forest Service (Bergeron 


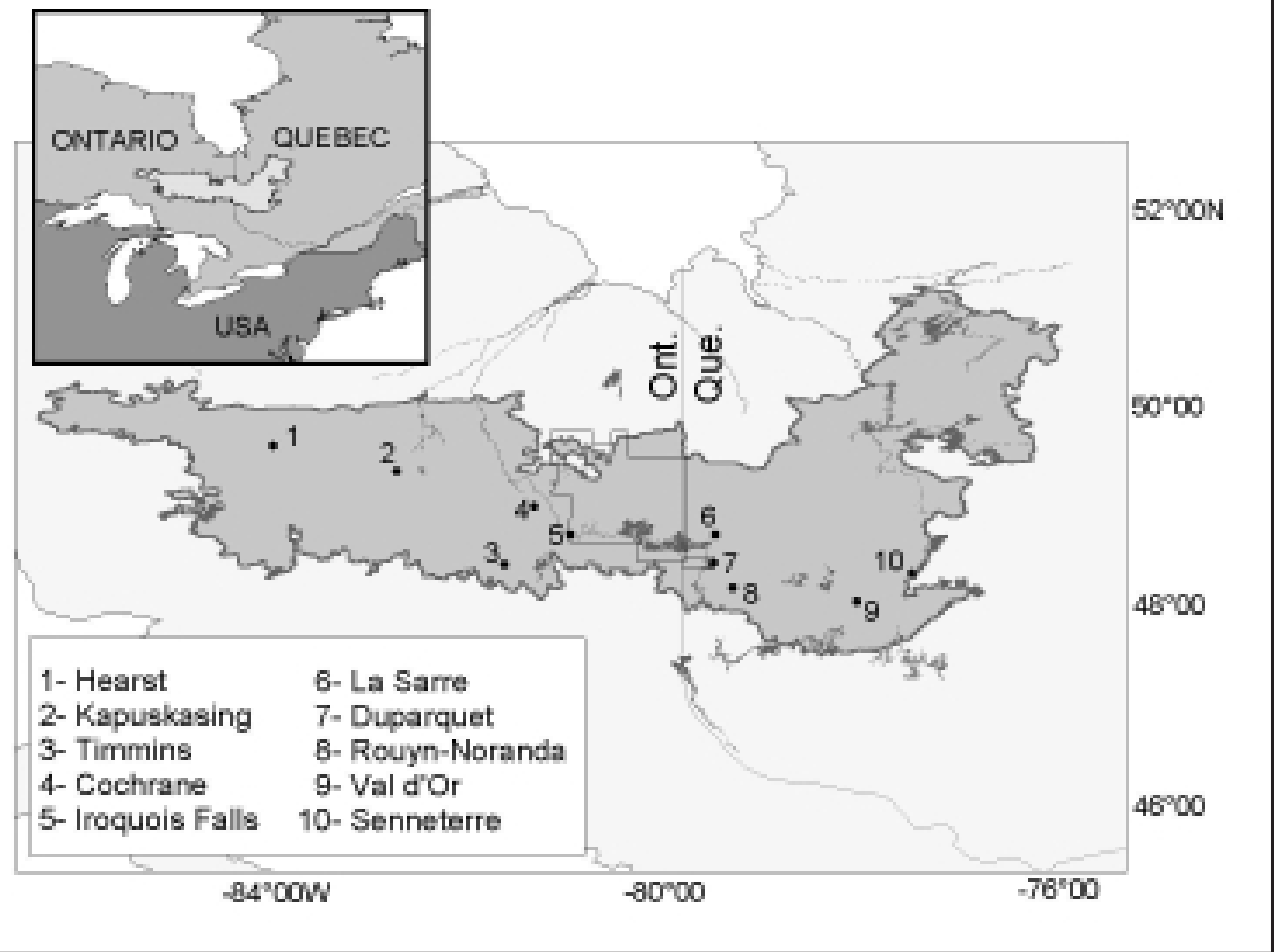

Fig. 1. Claybelt region showing, on each side of the border, the Lake Abitibi Model Forest (LAMF, Ontario) and the Lake Duparquet Research and Teaching Forest (LDRTF, Quebec.)

et al. 1999). The article will provide a brief overview of the concepts of the model and its current applications in the southern and northern sections of the Claybelt. The following topics are covered in the Claybelt Knowledge Synthesis publication: natural forest dynamics (Parts I and II), past and present silvicultural practices (Part III), impacts of forest management on biodiversity (Part IV), forest management (Part V), and the 3-cohort model and its current applications (Part VI).

\section{The Claybelt Region}

The Claybelt covers a broad east-west band of land that straddles the Ontario-Quebec border and covers about $125000 \mathrm{~km}^{2}$ (Fig. 1). The southern portion is situated in the boreal mixedwood forest, whereas the black spruce boreal forest dominates the landscape north of the $49^{\text {th }}$ parallel. Topography is nearly level; the Claybelt features vast lowlands of poorly drained clay soils, the result of lacustrine deposits from glacial Lake Barlow-Ojibway (Hills 1959, Richard 1980). The poor drainage together with the cold, wet climate has resulted in the development of organic soils that cover a large portion of the region (Ketcheson and Jeglum 1972).

\section{Part I - Description of the Claybelt Forest}

The composition of the mixedwood and black spruce boreal forests is primarily the product of climate, site factors and time elapsed since the last disturbance (Gauthier et al. 2000). On well-drained sites, jack pine often increases proportionally after a fire compared to black spruce in the more northerly black spruce region, whereas trembling aspen and white birch tend to be favoured after fire in the mixedwood boreal forest. In the prolonged absence of fire, forest succession leads to more abundant balsam fir and white spruce in the mixedwood boreal forest, and black spruce in both the mixedwood and black spruce boreal forests (Gauthier et al. 2000). White birch and jack pine are more abundant on well-drained shallow and coarse-textured soils, while aspen is more often found on mesic clays. Black spruce is common on all deposit types, but regenerates by layering most often on organic and poorly drained clay soils (McEwen 1966, Taylor et al. 1987). Black spruce stands generally begin to lose their even-age structure and merchantable volume between 100 and 125 years of age, as individual stem mortality is accompanied by an opening up of the canopy (Harper et al. 2002). Resulting gaps foster layering and height growth of layers, which sometimes account for over $80 \%$ of advance regeneration in black spruce stands (Groot 1984, Archibald and Arnup 1993). In the absence of fire, this recruitment process can lead to the establishment of a second and subsequent cohorts of black spruce, especially in the northern portion of the Claybelt.

\section{Part II - Natural Disturbance Dynamics}

While windfall, insect outbreaks and other disturbances do occur in the Claybelt, the discussion here is limited to fire disturbance because fires have been the dominant disturbance affecting the structure and composition of the Claybelt landscape. Fires in the Claybelt may recur less often than in other regions partly because of the vast expanses organic and poorly drained clay deposits; nonetheless they do initiate secondary forest succession (Dansereau and Bergeron 1993). Despite the occurrence of crown fires, burned areas frequently feature remnant patches often composed of deciduous or mixedwood stands, which are less flammable than coniferous stands (Kafka et al. 2001, Bergeron et al. 2002).

During Phase II of Canada's Model Forest Program (1997-2002), LAMF supported historical fire reconstruction projects of the Model Forest land base, as part of a program of 
landscape-level research. The work complemented recent fire mapping exercises just across the provincial border, thus helping to produce a picture of natural landscape disturbance history across the Claybelt (Gauthier et al. 2002).

Fire reconstruction studies in the Claybelt indicate that the average age of the forest (number of years without fire) is 172 years in LAMF and 139 years in Quebec (Bergeron et al. 2001). Of the stands present today, about $75 \%$ and $60 \%$ respectively would be over 100 years old if there had been no logging or spruce budworm epidemics. The fire cycle - the time required to burn an area equivalent to the study area-was 132 years in the LAMF and 83 years in Quebec prior to 1850 , rising to 521 years and 325 years respectively for the period of 1920-1999. This reduction in burned area is believed to be due primarily to climate change, and a subsequent reduction in the fire hazard (Bergeron 1991, Flannigan et al. 1998), and by fire suppression activities (Lefort et al. accepted). Thus, while the Claybelt has certainly had some very big fires, a large portion of the forest is made up of uneven-aged, multi-storeyed stands that are over 150 years old (Groot and Horton 1994).

\section{Part III - Silvicultural Practices}

Horse logging began in 1912, after the area was opened up by railway construction (Perron 1989). Logging was generally done in winter, since the poor drainage of the clay lowlands made summer operations almost impossible over a large area. Selective horse logging of peatland black spruce left behind abundant advance regeneration (Mulloy 1937). Today, these second growth stands have an irregular age structure similar to that of natural old-growth black spruce stands ( $>160$ years) (Groot and Horton 1994).

In the 1950s, as the distance from logging areas to mills increased and technology advanced, the use of tracked skidders, and later wheeled skidders, gradually replaced horses (Brumelis and Carleton 1988). In the second half of the $20^{\text {th }}$ century, volumes harvested, both per hectare and annually, increased as clearcuttingthe most cost-effective logging method for end products such as pulp, paper and small dimension softwood lumber-became the practice of the day (Groot 1994).

Of course, mechanized harvesting has created some regeneration problems (Bonner 1960, Brumelis and Carleton 1989). Competition from ericaceous shrubs and alder has been reported for black spruce peatlands (Vincent 1964), while sedges, grasses, woody shrubs and non-commercial hardwoods tend to invade rich sites on the mixedwood uplands (Harvey et al. 1995, Nguyen-Xuan et al. 2000). To make up for deficiencies in natural regeneration, artificial regeneration-planting or seeding - has been used extensively in the Claybelt (Groot and Adams 1994).

The use skidders in the 1970s and 1980s extended logging into the summer season and, as a result, soil compaction and rutting due to clearcutting have been well documented for the Claybelt. The extensive clay and organic soils of the Claybelt make it one of the most susceptible regions in Ontario and Quebec to compaction and rutting (Brais and Camiré 1998, Schreiber and Jetté 1998). Use of wide-tired skidders, repeated use of the same forwarding trails (careful logging), and winter logging have contributed to reducing soil disturbance during harvesting activities (MacDonell and Groot 1996); however, aside from winter logging, it is very difficult—nor is it necessarily desirable — to eliminate site disturbance entirely (Groot 1998).
During Phase II (1997-2002), as part of a program of standlevel research and development, LAMF supported studies that contributed to the knowledge of site disturbance in the Claybelt. This knowledge, combined with best management practices from other regions, was the basis for a practical field guide produced by LAMF for resource managers and equipment operators in Northeastern Ontario, aimed at minimizing soil disturbance in forestry operations (Arnup 2000).

Problems related to clearcutting led to the development of harvesting methods aimed at protecting site integrity and advance regeneration. Over the last decade, CLAAG (careful logging around advance growth) in Ontario and CPRS (French acronym meaning "logging with protection of advance growth and soils") in Quebec, have become the most common harvesting method in the Claybelt. CLAAG-CPRS limits movements of machinery to regularly spaced corridors, thus reducing overall site disturbance, favouring genetically adapted advance growth and reducing regeneration costs (Archibald and Arnup 1993). However, management of advance regeneration is a complex matter and there are few forecasting tools available to provide planning guidance (Harvey and Brais 2002).

Another harvesting system that is gaining increased use in Ontario and Quebec is designed to protect small merchantable trees (diameters up to $15 \mathrm{~cm}$ ) in multi-storeyed, uneven-aged stands. Known as HARP (harvesting with regeneration protection) in Ontario and CPPTM (French acronym meaning "cutting with protection of small merchantable trees") in Quebec, this technique has some similarity to early $20^{\text {th }}$ century horse $\log$ ging. LAMF has supported studies and promoted the HARP technique in the boreal forest of Ontario (Groot 2000). Currently HARP-CPPTM is only used on a small scale in the Abitibi area, despite the high proportion of uneven-aged stands in the Claybelt. HARP-CPPTM is considered to present several advantages over conventional clearcutting or careful logging: i) reduced time between harvests, ii) improved visual appeal, iii) habitat conservation through improved protection of residual trees, iv) maintenance of uneven-aged structure characteristic of older stands, and v) reduced invasion of stands by deciduous trees.

In Ontario, LAMF has contributed significantly to the development of forest management techniques, particularly those implemented by Abitibi-Consolidated Inc. (Kliewer 1997). The Model Forest supported a study of harvesting systems aimed at maintaining residual stands with an uneven size structure (MacDonell and Groot, 1997). This work formed part of the base knowledge that led to the recognition in the provincial silvicultural guide of HARP as a harvest method under the clearcut silvicultural system (OMNR 1997).

\section{Part IV - Biodiversity}

One of the major challenges for the forestry industry is maintaining wildlife habitat diversity within its natural range of variability. Changes in the composition and structure of the natural forest mosaic may have implications for biodiversity because wildlife reacts to the different types of vegetation cover (Welsh and Venier 1996). This point is illustrated using studies that have focussed on a number of indicators: birds, woodland caribou, lichens and bryophytes.

A landscape-scale research project in the mixedwood region studied the effect on birds of conversion of mixed stands to intolerant hardwoods following logging. Compared to the natural 
mosaic, landscapes affected by logging exhibit a reduction in average species richness of mature-forest bird species (Drapeau et al. 2000). Another study in the black spruce forest region has demonstrated that bird species distribution is associated with changes in stand structure, which varies with the time since the last fire (Drapeau et al. 1999). The study also highlighted the importance of recent burns for primary cavity excavators, notably the black-backed woodpecker (Picoides arcticus) which was found in densities ten times greater in one-year-old burns than in other forest age-classes (Nappi 2000).

Woodland caribou ranges over large areas $\left(500 \mathrm{~km}^{2}\right.$ to $2000 \mathrm{~km}^{2}$ ) in the northern part of the Claybelt and animals are known to move between the two provinces, (Rettie et al. 2001), but knowledge of the ecology of the species is still fragmentary. While extensive logging, and the development of new logging areas, may cause habitat deterioration and increase predation risk (Cumming and Beange 1993, Thompson and Welsh 1993), it is possible to monitor caribou movement and limit harvesting in sensitive areas. Wilson (2000) reported that caribou wintering grounds are open (3-13 trees $\left./ 100 \mathrm{~m}^{2}\right)$, suggesting that these areas may be of less value to the forest industry. Ground and epiphytic lichens are important food sources for caribou (Wilson 2000). However, logging leads to a reduction in epiphytic species such as Evernia mesomorpha and Usnea spp. for up to $50 \mathrm{~m}$ from the forest edge (Rhéault 2002). In virgin black spruce forests, epiphytic lichens reach their maximum development in overmature stands and then decline in unevenaged old-growth stands (>200 years) (Boudreault et al. 2002). As well, although composition of lichen or bryophyte communities will vary with time since the last fire, species diversity has not been found to be greater in old-growth black spruce forests. In contrast, in the mixedwood region of the Claybelt, certain lichens and bryophytes are found only in old-growth (>200 years) aspen stands (Boudreault et al. 2000).

LAMF has been instrumental in advancing knowledge of landscape-level effects of natural disturbance vs. harvesting disturbance in the Ontario Claybelt. Work has been well coordinated with similar studies in the mixedwood section of the Claybelt in Quebec. This collaboration will continue, as LAMF moves into Phase III, and the Sustainable Forest Management Industrial Chair at UQAT undertakes a landscape-level study in the black spruce zone to determine factors that are key to the maintenance of biodiversity in this zone. Because cumulative effects of forest harvesting are thought to be equally or more important than immediate local effects on biodiversity, it is clear that a landscape or regional framework will ultimately provide the best approach to linking forest management with biodiversity maintenance.

\section{Part V - Knowledge Applications to Forest Management}

Forest management in the Claybelt poses some unique challenges. In the black spruce region in particular, in the absence of fire, secondary disturbances and recruitment by layering result in the creation of a forest mosaic dominated by multistoreyed, uneven-aged stands. These forests are generally characterised by low-volume stands containing a large number of small merchantable stems of layer origin, often with pronounced curves at the stump. These stand conditions result in relatively high costs for harvesting and sawmill processing (Arnup et al. 1988, Whynot and Penner 1992).
While CLAAG-CPRS currently accounts for over $80 \%$ of logged areas in the Claybelt, the appropriateness of generalising this type of harvesting has been questioned (Bergeron et al. 1999, 2002). CLAAG-CPRS tends to reduce the natural structural variability of the forest (increased homogeneity) and ultimately reduces wildlife habitat. Consequently, HARPCPPTM has been proposed as an appropriate harvesting method in uneven-aged stands because it maintains or creates the irregular and more open structure of old-growth black spruce forests. In many respects, HARP-CPPTM creates a residual stand structure similar to conditions produced by horse logging in the first half of the last century. Current information on second-growth stands suggests that this type of harvesting is viable (Groot and Mattice 1995).

\section{Management based on natural forest dynamics}

In Ontario, forest policy requires that cutting patterns reflect the configuration created by fires in order to maintain landscape patterns similar to the natural forest mosaic. As well, variable retention guidelines for leaving aggregated patches and dispersed standing trees in cutovers have been developed to assure that the spatial patterns and structural attributes of harvested areas more closely resemble those of forests disturbed by fire and thus provide refuge for certain organisms. In contrast, the recently modified Forest Law in Quebec does not clearly put the province on the road to natural disturbance-based forest management. This is a curious situation in that the research work undertaken in the Lake Abitibi Model Forest and the Quebec side of the Claybelt has often been cited as providing a viable solution to reconciling forestry and biodiversity maintenance in the boreal forest. This said, forthcoming modifications to Quebec forest regulations are expected to incorporate a number of natural disturbance-based guidelines similar to those in Ontario.

Sustainable forest management is an evolving concept and ecological, economic and social values vary among regions and stakeholders. While a great deal has been learned about the ecology and management of the Claybelt forest ecosystem, many questions still remain. Is there an optimum balance between forest area that should be harvested using CLAAG-CPRS, HARPCPPTM and other methods? Is over-age and old-growth forest an essential part of ecosystem diversity in the Claybelt? If so, how much should be maintained and can we maintain key structural attributes of older stands in forests that are partially harvested? Although individually, these questions are difficult to answer, a coarse-filter management approach, such as proposed in the 3-cohort model, provides a framework to address concerns about maintaining forest mosaic diversity. Part VI develops the concept of ecosystem management by presenting the 3-cohort model and examples of its application.

\section{Part VI - The 3-cohort model and its application}

The "cohort model," as it has become known, was introduced by Bergeron et al. (1999). In effect inspired by an improved understanding of fire history and forests dynamics gained through research work in northwestern Quebec and the Lake Abitibi Model Forest, the model presents a forest management approach which emphasizes maintaining a forest age structure and composition similar to those generated by the regional disturbance regime driven by fire. 
The cohort approach is currently being applied in two distinct forest management projects in the Claybelt of Quebec: one in the southern mixedwood section at the Lake Duparquet Research and Teaching Forest, about $40 \mathrm{~km}$ south of the town of La Sarre, and the other, on the "Lac Grasset Section" of a Forest Management Unit under licence to Tembec and Norbord-Nexfor, situated about $125 \mathrm{~km}$ north of La Sarre, in the more northerly, black spruce region. The two projects are different in a number of respects. For example, the Lake Duparquet Forest, managed by the Université du Québec en Abitibi-Témiscamingue and Université du Québec à Montréal in collaboration with Tembec and Norbord, covers only $80 \mathrm{~km}^{2}$, whereas the Lac Grasset area occupies about $4750 \mathrm{~km}^{2}$, of which approximately $50 \%$ is commercial forest. The Lake Duparquet is currently managed on an area-basis while annual allowable cut for Lac Grasset was determined using the same volume-based model, SYLVA II, as all forest companies are required to use in Quebec. Despite these differences, the conceptual bases and methodology used in the two projects are quite similar. In essence, they are based on the same working hypotheses:

1. That the natural forest mosaic is the expression of the interrelated forces of climate, site factors, disturbance regime and vegetation dynamics;

2. That forest structure, or forest structure and composition, change with time since fire;

3. That the application of certain partial cutting treatments can create residual stand structures and compositions that resemble those of older seral stages;

4. That it is possible, by diversifying harvesting treatments, to maintain or generate the structural and compositional attributes of a regional forest mosaic similar to what the natural disturbance regime would produce.

In effect, this last hypothesis constitutes the ecological rationale for the approach, in that it implies that maintaining the structural and compositional characteristics of a natural mosaic is essential to maintaining its biodiversity. The corollary to this is that biodiversity is lost when parts of the natural mosaic (i.e., over-mature and old-growth forests) are eliminated from the regional landscape through conventional forest regulation under even-age management. A similar hypothesis has been proposed concerning the effect of eliminating recently burned forests by salvage cutting.

The following is a brief description of the framework used for developing the cohort approach. (See also Bergeron et al. 2002, Harvey et al. 2002). First, fire history studies were undertaken in order to characterize and quantify various disturbance parameters, such as forest age distribution, fire cycle, frequency and size distribution, and variations in fire severity. Other major disturbances that affect forest composition and structure, such as spruce budworm outbreaks, have also been documented. Second, field studies on site-specific forest dynamics, aided by time-since-fire and forest ecosystem maps, provided a means of characterizing composition and structural changes of stands or forest types through time. Information on species composition (fire-adapted, shade-intolerant species versus late successional, shade tolerants) and structure (even-aged, uneven-aged-irregular or open), is used to associate stands with one of three cohorts, roughly corresponding to three broad successional stages: even-agedpioneer; uneven-aged and overmature; and uneven-aged, irregular or open "old growth." Based on the theoretical, negative exponential forest age distribution for any fire cycle and maximum harvest age, Bergeron et al. (1999) provide a table which presents the percentage of a regional landscape to be maintained in each cohort.

Using this framework, silvicultural trials have been set up, both in the Lake Duparquet Forest (see http://web2.uqat.uquebec.ca/safe/) and in the black spruce region to evaluate the operational feasibility of partial cutting treatments including "succession cutting" and HARP-CPPTM and their effects on stand attributes such as composition, structure, coarse woody debris, and certain biodiversity indicators. The objective here, of course, is to determine whether certain partial cutting treatments do, in fact, produce stands containing key attributes found in older, natural stands.

The cohort approach is integrated at all planning levels. At the strategic level, forest composition and age structure objectives are established to maintain landscape diversity and management scenarios using different treatments are developed to evaluate effects on annual allowable cut. At the five-year, tactical planning level, the focus is on spatialization of harvest areas, with attention placed, at least in the Lac Grasset project, on attempting to incorporate spatial aspects of natural fires. Finally, at the operational level, the cohort classification of forest types, based on stand structure and composition, is used to attribute appropriate silviculture treatments to stands.

\section{Conclusion}

Lake Abitibi Model Forest's Knowledge Synthesis Project has brought together ecological and management information and research findings accumulated over the last fifty years in the Claybelt of Ontario and Quebec. The Knowledge Synthesis is one pillar in a LAMF Phase II collaborative program that yielded a number of "on-the-ground" results. A field tour across the Claybelt drew active participation from Ontario and Quebec foresters and researchers; a site catalogue was initiated to characterize site conditions faced by managers across the region; a comprehensive database compiled relevant research and silvicultural trials for reference by researchers, foresters, and planners. Together, these projects helped link people across the Claybelt, a unique ecological region through which a provincial boundary happens to run.

The attributes of this region of the boreal forest, most notably the extensive black spruce peatlands and an age structure that includes large areas of forest over 100 and even 200 years old, have strongly influenced the evolution of regional forest management. This evolution includes the development and current experimentation of the management approach "by cohorts" in northwestern Quebec. Given Ontario's emphasis on the natural disturbance template as a basis for forest management, there is a developing interest to initiate similar projects in that province. LAMF will continue to facilitate and promote collaboration by researchers and forest managers in both provinces, and will help draw upon collective knowledge to bring "on-the-ground" results to forest management across the Claybelt.

\section{Acknowledgements}

The contribution of the many individuals who worked on the Knowledge Synthesis Project is gratefully acknowledged. 


\section{References}

Archibald, D.J. and R.W. Arnup. 1993. The management of black spruce advance growth in northeastern Ontario. Northeast Sci. and Technol., Ont. Min. Nat. Resour., Timmins, Ont. Tech.Rep. 008. VMAP Tech. Rep. No. 93-05. 32 p.

Arnup, R.W. 2000. Minimising soil disturbance in forestry operations. The Lake Abitibi Model Forest, Cochrane, Ont. 26 p.

Arnup, R.W., B.A. Campbell, R.P Raper, M.F. Squires, K.D. Virgo, V.H. Wearn and R.G. White. 1988. A silvicultural guide for the spruce working group in Ontario. OMNR Sci. \& Tech. Series V.4.

Bergeron, Y. 1991. The influence of island and mainland lakeshore landscapes on boreal forest fire regimes. Ecology 72: 1980-1992.

Bergeron, Y., B. Harvey, A. Leduc and S. Gauthier. 1999. Forest management guidelines based on natural disturbance dynamics: Stand-and forest level considerations. For. Chron.75: 49-54.

Bergeron, Y., S. Gauthier, V. Kafka, P. Lefort and D. Lesieur. 2001. Natural fire frequency for the eastern Canadian boreal forest: consequences for sustainable forestry. Can. J. For. Res. 31: 384-391. Bergeron, Y., A. Leduc, B.D. Harvey and S. Gauthier. 2002. Natural fire regime: a guide for sustainable management of the Canadian boreal forest. Silva Fennica 36: 81-95.

Bonner, E. 1960. Reforestation problems in eastern spruce forests. For. Chron. 36: 153-155.

Boudreault, C., S. Gauthier and Y. Bergeron. 2000. Epiphytic lichens and bryophytes on Populus tremuloides along a chronosequence in the southwestern boreal forest of Québec. Canada. Bryologist 103: $725-738$.

Boudreault, C., Y. Bergeron, S. Gauthier and P. Drapeau. 2002. Bryophyte and lichen communities in mature to old-growth stands in eastern boreal forests of Canada. Can. J. For. Res. (in press).

Brais, S. and C. Camiré. 1998. Soil compaction induced by careful logging in the Claybelt region of northwestern Québec (Canada). Can. J. Soil. Sci. 78: 197-206.

Brumelis, G. and T.J. Carleton. 1988. The vegetation of postlogged black spruce lowlands in central Canada. I. Trees and tall shrubs. Can. J. For. Res. 18: 1470-1478.

Brumelis, G. and T.J. Carleton. 1989. The vegetation of post-logged black spruce lowlands in central Canada. I. Understorey vegetation. J. Appl. Ecolo. 26: 321-339.

Cumming, H.G. and D.B. Beange. 1993. Survival of woodland caribou in commercial forests of northern Ontario. For. Chron. 69: 579-588.

Dansereau, P.R. and Y. Bergeron. 1993. Fire history in the southern boreal forest of northwestern Québec. Can. J. For. Res. 23: 25-32.

Drapeau, P., A. Leduc and R. McNeil. 1999. Refining the use of point counts at the scale of individual points in studies of birdhabitat relationships. J. Avian Biol. 30: 367-382.

Drapeau, P., A. Leduc, J.F. Giroux, J.P.L. Savard, Y. Bergeron and W. Vickery. 2000. Landscape-scale disturbances and changes in bird communities of boreal mixed-wood forests. Ecol. Monogr. 70: $423-444$

Flannigan, M.D., Y. Bergeron, O. Engelmark and B.M. Wotton. 1998. Future wildfire in circumboreal forests in relation to global warming. J. Veg. Sci. 9: 469-476.

Gauthier, S., L. De Grandpré and Y. Bergeron. 2000. Differences in forest composition in two boreal forest ecoregions of Québec. J. Veg. Sci. 11: 781-790.

Gauthier, S., P. Lefort, Y. Bergeron and P. Drapeau. 2002. Time Since Fire Map, Age-class Distribution and Forest Dynamics in the Lake Abitibi Model Forest. Natural Resources Canada, Canadian Forest Service, Laurentian Forestry Centre, Information Report LAU-X-125. (in press).

Groot, A. 1984. Stand and site conditions associated with abundance of black spruce advance growth in the Northern Clay section of Ontario. Can. Dep. Environ., Can. For. Serv., Sault Ste. Marie, Ont. Inf. Rep. O-X-358. 20 p.
Groot, A. 1994. Silvicultural systems for black spruce ecosystems. In C.R. Bamsey. Proceedings: Innovative silviculture systems in boreal forests. Symposium held in Edmonton, Alberta, Canada. pp. 47-51. Groot, A. 1998. Physical effects of site disturbance on peatlands. Can. J. Soil Sci. 78: 45-50.

Groot, A. 2000. Fifth-year results of two silvicultural experiments in peatland black spruce. Report submitted to the Lake Abitibi Model Forest. $22 \mathrm{p}$

Groot, A. and M.J. Adams. 1994. Direct seeding black spruce on peatlands: fifth-year results. For. Chron. 70: 585-592.

Groot, A. and B.J. Horton. 1994. Age and size structure of natural and second-growth peatland Picea mariana stands. Can. J. For. Res. 24: 225-233.

Groot, A. and C.R. Mattice. 1995. Second-growth black spruce stands on peatlands provide lessons for current silviculture. Can. For. Serv., Sault Ste. Marie, Ont. Frontline, Tech. Note 62.

Harper, K., Y. Bergeron, S. Gauthier and P. Drapeau. 2002. Postfire development of canopy structure and composition in black spruce forests of Abitibi, Québec: a landscape scale study. Silva Fennica (in press).

Harvey, B. and S. Brais. 2002. Effects of mechanized careful logging on natural regeneration and vegetation competition in the southeastern Canadian boreal forest. Can. J. For. Res. 32: 653-666. Harvey, B., A. Leduc and Y. Bergeron. 1995. Early postharvest succession in relation to site type in the southern boreal forest of Québec. Can. J. For. Res. 25: 1658-1672.

Harvey, B.D., A. Leduc, S. Gauthier and Y. Bergeron. 2002. Standlandscape integration in natural disturbance-based management of the southern boreal forest. For. Ecol. Manag. 155: 369-385.

Hills, G.A. 1959. A ready reference to the description of the land of Ontario and its productivity. Ont. Dept. Lands and For., Division of Research, Maple, Ont. 142 p.

Kafka, V., S. Gauthier and Y. Bergeron. 2001. Fire impacts and crowning in the boreal forest: study of a large wildfire in western Québec. Int. J. Wild. Fire 10: 119-127.

Ketcheson, D.E. and J.K. Jeglum. 1972. Estimates of black spruce and peatland areas in Ontario. Dep. Environ., Can. For. Serv., Sault Ste. Marie, Ont. Inf. Rep. O-X-172.

Kliewer, N. 1997. Operational trials of careful logging techniques within the Iroquois Falls Forest. Report prepared for Abitibi-Consolidated Inc., Iroquois Falls, Ont. 17 p.

Lefort, P., S. Gauthier and Y. Bergeron. The influence of fire weather and land use on the fire regime of the Lake Abitibi area, eastern Canada. Forest Science (accepted).

MacDonell, M.R. and A. Groot. 1996. Uneven-aged silviculture for peatland second-growth black spruce: biological feasibility. Nat. Resour. Can., Can. For. Serv., Great Lakes Forestry Centre, Sault Ste. Marie, Ont. NODA/NFP Tech. Rep. TR-36. 14p.

MacDonell, M.R. and A. Groot. 1997. Harvesting peatland black spruce: impacts on advance growth and site disturbance. For. Chron. 73(2): 249-255. McEwen, J.K. 1966. An effect of sphagnum on the growth of black spruce. For. Chron. 42: 175-183.

Mulloy, G.A. 1937. Silvicultural practice in pulpwood forests. Canadian Pulp and Paper Assoc., Woodlands Section, WSI No. 384 (F-2). 11 p.

Nappi, A. 2000. Distribution des pics et utilisation des arbres morts dans les forêts soumises aux perturbations naturelles en pessière à mousses. Mémoire de maîtrise. Département des sciences biologiques. Université du Québec à Montréal, Montréal, Québec.

Nguyen-Xuan, T., Y. Bergeron, D. Simard, J.W. Fyles and D. Paré 2000. The importance of forest floor disturbance in the early regeneration patterns of the boreal forest of western and central Québec: a wildfire versus logging comparison. Can. J. For. Res. 30: 1353-1364. OMNR. 1997. Silvicultural guide to managing for black spruce, jack pine, and aspen on boreal forest ecosites in Ontario. Version 1.1. Ont. Min. Nat. Resour., Queen's Printer for Ontario, Toronto. 3 books. $822 \mathrm{p}$. 
Perron. 1989. L'exploitation forestière dans la région de La Sarre de 1910 à 1980. Capitale forestière du Canada inc., La Sarre, Québec. 46 p.

Rettie, J., J. Wilson and G. Brown. 2001. Woodland caribou in northeastern Ontario. New knowledge: Solutions for forest management. January 29-30, 2001. Timmins, Ontario.

Rhéault, H. 2002. Effet de bordure sur la distribution des lichens épiphytes des forêts aménagées en zone de pessière noire à mousses Mémoire de maîtrise. Département des sciences biologiques. Université du Québec à Montréal, Montréal, Québec.

Richard, P. 1980. Histoire postglaciaire de la végétation au sud du lac Abitibi, Ontario et Québec. Géogr. Phys. Quat. 34: 77-94.

Rowe, J.S. 1972. Forest regions of Canada. Dep. Environ., Can. For. Serv. Publ. 1300. 172 p.

Schreiber, A. and J.P. Jetté. 1998. L'ornièrage après coupe dans les milieux forestiers humides. Note technique. Dir. de l'Env. For. Ministère des Ressources naturelles du Québec, Gouv. du Québec. 4 p.

Taylor, S.J., T.J. Carleton and P. Adams. 1987. Understorey vegetation change in a chronosequence. Vegetatio, 73: 63-72.
Thompson, I.D. and D.A. Welsh. 1993. Integrated resource management in boreal forest ecosystems -impediments and solutions. For. Chron. 69: 32-39.

Vincent, A.B. 1964. Growth and numbers of speckled alder following logging of black spruce peatlands. For. Chron. 40: 514-518.

Welsh, D.A. and L.A. Venier. 1996. Binoculars and satellites: developing a conservation framework for boreal forest wildlife at varying scales. For. Ecol. Manag. 85: 53-65.

Whynot, T.W. and M. Penner. 1992. Growth and yield of black spruce ecosystems in the Ontario Claybelt: implications for forest management. Petawawa National Forestry Institute, Chalk River, Ont. Inf. Rep. PIX-99.

Wilson, J.E. 2000. Habitat characteristics of late wintering areas used by woodland caribou (Rangifer tarandus caribous) in northeastern Ontario. Submitted in partial fulfilment of the requirements for the degree of Masters of Science. School of Graduate Studies and Research, Laurentian University, Sudbury, Ontario. 